\title{
MODERATING ROLE OF CORPORATE REPUTATION IN THE INFLUENCE OF EXTERNAL SUPPORT ON ORGANISATIONAL RESILIENCE AND PERFORMANCE
}

\author{
ANNA ZABŁoCKA-KLUCZKA ANNA SAŁAMACHA
}

\begin{abstract}
A B STR A C T
The article analyses the influence made by corporate reputation on the mediation model for the impact of external support on organisational performance through resilience. The article aims to clarify the mechanism behind the moderating role of corporate reputation played in the influence of external support on organisational performance and considering the mediating role of organisational resilience. The empirical research was made to verify the existence of the relationship and to reach the aim of the paper. The set of hypotheses was built based on the theoretical research and then verified on the sample of 268 organisations operating in Poland. Dependences among the data selected from the theoretical research were analysed using statistical methods, including the correlation with the moderator and the mediated regression analysis. The obtained results clearly showed that corporate reputation was a moderator of the discussed mediation model for the influence of the external support on organisational performance through resilience. The paper contributes to further development of knowledge in organisational resilience management. It clarifies and stresses the role of two external factors: corporate reputation and external support in shaping the resilience of an organisation and its performance. The obtained results imply specific practical recommendations. Since corporate reputation can be the key to achieving greater organisational resilience and performance, special attention should be given to managing this category in an organisation.
\end{abstract}

KEY WORDS

management, corporate reputation, organisational resilience, external support, organisational performance

10.2478/emj-2020-0021
Anna Zabłocka-Kluczka

Wrocław University of Science and Technology, Poland ORCID 0000-0002-4743-2375

Corresponding author: e-mail: anna.zablocka-kluczka@pwr.edu.pl

Anna Sałamacha

Wrocław University of Science and Technology, Poland ORCID 0000-0002-9601-4620

\section{INTRODUCTION}

Undesirable, potentially disruptive and crisescausing factors are constantly present in the surroundings of contemporary organisations. All organisations encounter such factors; however, some are able to prosper even despite the catastrophic events that occur, while others go bankrupt. The attribute that distinguishes the first group of organisations is perhaps the most desirable nowadays, i.e., organisational resilience, usually under-

Zabłocka-Kluczka, A., \& Sałamacha, A. (2020). Moderating role of corporate reputation in the influence of external support on organisational resilience and performance. Engineering Management in Production and Services, 12(3), 87-102. doi: $10.2478 / \mathrm{emj}-2020-0021$ 
stood as the ability to withstand shocks ("to adapt to, resist and recover from external shocks" (Pirotti \& Venzin, 2017, p. 1)). There is still a long way to build a complete, fully accepted concept of organisational resilience. The literature derives and discusses different drivers of organisational resilience, which vary widely across studies. However, most researchers agree that the most important drivers include situation awareness, preparedness, responsiveness, resourcefulness, redundancy, robustness, rapidity, adaptability, agility, integrity, learning processes or organisational culture (Norris et al., 2008; Scholl \& Patin, 2012; Bruneau et al., 2003; Wicker et al., 2013; Kantur \& Iseri-Say, 2015; Koronis \& Ponis, 2018). The observation by Seville that an "organisation can become more resilient if it wants to" (Seville, 2017, p. 2), draws the attention to the meaning of internal factors and the causative role of management and managers in the process of shaping the organisational resilience. The literature mainly focuses on the discussion of these issues. However, external factors - such as external support - also have the potential to shape organisational resilience. This factor is rather rarely discussed and definitely does not belong to the mainstream of research concerning organisational resilience. However, it can be a source of interesting findings for organisational resilience management.

Organisations can seek external support in various situations: for the development of new products or innovation potential, for creating alliances necessary to achieve mutual benefits or under the pressure of circumstances, e.g., during a crisis, when the existence of the organisation is at stake. It is always a possibility and not an obligation; nevertheless, it involves the fulfilment of certain obligations, formal or moral. External support may be institutional (usually, governmental or, e.g., provided by the EU) or come from non-governmental and non-institutional stakeholder groups (suppliers, stockholders, customers, etc.). In the first case, organisations have to meet certain conditions (imposed by the supporting institution). In the second case, however, an organisation deals with stakeholder perceptions of its reputation, which is a kind of patchwork of previous stakeholder experiences gained dealing with the organisation, as well as of possible future benefits gained due to the ability of the organisation "to satisfy their interests" (Pérez-Cornejo et al., 2019). These perceptions become an important factor that determines the scope of external support. This reality has been clearly confirmed during the COVID-
19 pandemic in many countries of the world and especially for SMEs. In an attempt to avoid losing thousands of well-functioning businesses permanently, governments of many countries proposed institutional support instruments (i.e., deferring or extending payment deadlines, looking for alternative ways of distributing goods, providing nonreturnable subsidies, taking over debts and liabilities of companies, or proposing credit programmes to ensure the liquidity of companies). Different measures were more or less accessible to entrepreneurs depending on the country. However, the second important source of support was offered by non-governmental and non-institutional stakeholder groups. Based on the perceived reputation of organisations, stakeholders took a risk and agreed to pay in advance for the products and services to be received in an unknown future or to change contractual and service delivery terms. However, this support is far from selfless help as stakeholders always weigh the costs of lost benefits, i.e., broken supply chains, the lack of available services, the lack of favourite products or outlets. The support arose from links between organisations and imposed a moral obligation to fulfil promises in the future.

Hence, we have at least two important variables (external support and corporate reputation, both resulting from relationships with stakeholders) that can influence organisational resilience. Their interaction is not entirely clear. On the one hand, superior corporate reputation can attract some groups of stakeholders, e.g., customers and some form of support. On the other hand, perceptions of some stakeholder (i.e., the government) regarding good corporate reputation can lead to the conclusion that no such support is needed.

Hence, it seems to be a valid research gap. In this context, the article aims to clarify the mechanism behind the moderating role of corporate reputation in the influence made by external support on organisational performance, considering the mediating role of organisational resilience. To achieve this goal, first, a set of hypotheses were established; then, the needed variables (organisational resilience, external support, organisational performance and corporate reputation) were built. As a next step, relationships between all variables were examined, and then, a mediation model was built. Lastly, moderation analysis was performed in the context of the constructed mediation model. 


\section{LITERATURE OVERVIEW AND THE DEVELOPMENT OF HYPOTHESES}

\subsection{ORgANISATIONAL RESILIENCE AND ITS INFLUENCE ON ORGANISATIONAL PERFOR- MANCE}

In the organisational context, resilience is a multidimensional and sociotechnical phenomenon that addresses how organisations manage uncertainty (Lee et al., 2013). A widely accepted definition of organisational resilience has not yet emerged. It can be understood as a capacity, property, or an outcome, process or a state of an organisation (Hamel \& Välikangas, 2002; Kantur \& Iseri-Say, 2015; Vogus \& Sutcliffe, 2007), referring to the ability to survive and function successfully despite unfavourable conditions. It can also be understood as "maintenance of positive adjustment under challenging circumstances such that the organisation emerges from those conditions strengthened and more resourceful" (Vogus \& Sutcliffe, 2007, p. 3418), able to recognise and adapt to unexpected changes (Sutcliffe \& Vogus, 2003; Manyena, 2006; Lengnick-Hall et al., 2011; Lee et al., 2013; Linnenluecke, 2017; Koronis \& Ponis, 2018). According to McCann et al. (2009, p. 47), "an organisation also demonstrates resiliency be experiencing a severe, life-threatening setback, but then reinventing itself around its core values". Thus, not only the ability to adapt but also to reinvent is sometimes understood as organisational resilience. Various definitions give rise to various resilience drivers, which mainly refer to social and cultural factors, such as sensitivity to changes and situation awareness, preparedness and the keystone vulnerability management or adaptive capacity (Norris et al., 2008; Scholl \& Patin, 2012; Bruneau et al., 2003; Wicker et al., 2013; Kantur \& Iseri-Say, 2015; Koronis \& Ponis, 2018; Szydło \& Grześ-Bukłaho, 2020). They often serve as a basis for building tools for the assessment of organisational resilience. However, no single consistent scale has been created for measuring organisational resilience.

According to Lee et al. (2013), organisational resilience is a target, which is desirable although continuously moving. This is important not only in a crisis but also in the daily life of an organisation, as it contributes to performance during business as usual. Being resilient can provide organisations with competitive advantages, as there are similarities and links between organisational resilience and competitive excellence (Vargo \& Seville, 2010). Besides, the drivers of organisational resilience are, in many cases, the same as those that are needed to gain a competitive advantage (Mitroff et al., 1989; Mitroff, 2005). Some authors suggest possible links between organisational resilience and profitability (Sundström \& Hollnagel, 2006). According to them, "to be resilient, an organisation must be able to deal with unexpected and disruptive events as well as to understand the longer-term impact of such events. (...) this translates into the ability to identify and successfully manage risk at all levels in the organisation while sustaining a profitable business" (Sundström \& Hollnagel, 2006; p. 1). It is often underlined that resilience is the capacity to rebound from adversity strengthened and more resourceful (Sutcliffe \& Vogus, 2003). Therefore, to be resilient means to emerge stronger and to achieve positive potential outcomes (such as increased competitiveness or innovativeness, more adjusted internal processes or higher profitability). Carden et al. (2018) proved the existence of the relationship between organisational resilience and organisational performance from the financial aspect. The observation also seems to be valid in relation to other categories considered when measuring organisational performance. Concerning the above, the following hypothesis was formulated:

H1a. A relationship exists between organisational resilience and organisational performance.

\subsection{INFLUENCE OF EXTERNAL SUPPORT ON ORGANISATIONAL RESILIENCE AND PERFOR- MANCE}

Undoubtedly, modern organisations are unable to operate effectively without interacting with other market players. Bird (1988) emphasised that social, political, and economic variables, beside individual features of an organisation, created the context for conducting business activities. Hence, the ability to build a lasting relationship with the environment seems to be important, as it allows for "the acquisition of desired behaviour from the environment" (Sznajder, 2003, pp. 194-195), which may be crucial not only to survive but also to win a competitive fight. According to Gnyawali and Fogel (1994), the presence of local, financial and social encouragements significantly changed the entrepreneurial process. This means that external support influences the activities of an organisation as a whole.

External support should be generally understood as tangible and intangible resources provided by external bodies (various groups of stakeholders) to 
assist an organisation. According to Cheah et al. (2019), external support may be differentiated by the type of support (direct and indirect) and the type of a stakeholders (e.g., government, private or nonprofit). Direct support is typically financial (i.e., in the form of donations, grants, subsidies or earnings from any fundraising activities (Cheah et al., 2019)). Indirect support can be provided in all non-financial forms, e.g., various external sources of knowledge, information and expertise (Bala Subrahmanya, 2013). Organisations seek external support once they perceive a gap between the existing internal resources and the resources required to achieve business objectives (Carey, 2015). Thus, the use of external resources focuses on increasing competitiveness and development and, thus, on striving to achieve better results. However, Mambula (2004) emphasised that although the impact of external support on organisational performance has been studied many times (Cook, 2001; Warren \& Hutchinson, 2000), the reports are not explicit in this regard.

On the one hand, research results by Cook (2001) on small and medium-sized enterprises indicate a different level of organisational performance despite the same financial form. On the other hand, Carey (2015) proved that in the case of small and medium enterprises with indirect external support in the form of buying business advice, they achieved superior performance. This finding is consistent with research results by Mambula (2004), who believed that even in the case of exceptional internal resources, the lack of external support would result in insufficient performance. In addition, in studies on social organisations, Cheah et al. (2019) proved that both direct (financial) and indirect (training) support had a positive impact on organisational performance (both financial and social) through business planning. And finally, MacMahon (2001) showed that external funding dependence and financial advice were associated with better performance. Thus, considering the above, the following hypothesis can be assumed:

H1b. A relationship exists between external support and organisational performance.

By definition, each enterprise is a self-governing, independent and self-financing organisation, operating at its own risk and will. However, this independence of action means decision-making independence rather than a lack of business connections, as nowadays, it would be difficult to find an organisation that does not exert influence on other organisations or is not influenced by them. Organisations, as open systems constantly exchange resources with the environ- ment. It is often stressed that ensuring survival and providing the organisation with development opportunities under contemporary, increasingly turbulent environmental conditions, requires mastery in management. Furthermore, it is not just about the mastery in managing internal resources, but also, and perhaps above all, about the mastery in creating and managing relationships with the stakeholders and acquiring external resources.

Externally obtained resources can be crucial for the organisation's survival. According to McCann et al. (2009), having well-established external networks of relationships for accessing financial, human or other resources become essential in a crisis. Also, Tengblad and Oudhuis (2018) stated that to be resilient, organisations had to develop mutually trusting relationships with various groups of stakeholders (committed co-workers, loyal customers, reliable suppliers/partners, supportive owners, media, government, etc.). Such relationships can be treated as a kind of investment or insurance policy for poor times. They can also stimulate the customer citizenship behaviour perceived as non-obligatory consumer actions that create value for the company (DewalskaOpitek \& Mitręga, 2019), which can be especially important in a crisis. And "although establishing strong stakeholder relationships will not likely help an organisation avert every crisis, it can play an important role in how the organisation resolves a crisis it cannot avoid" (Ulmer, 2001, p. 593). First, it can decide whether the organisation receives any external help.

According to Ulmer (2001, p. 594), "if stakeholder relations are not strong, these groups may withdraw their support during a crisis, prolong the effects of a crisis, or intensify the threat associated with the event" and, thus, negatively affect the organisation's resilience. Second, it can determine the scope of external support that can be given to the organisation (from political support, purchase discounts and reasonable credit terms to sharing the crisis-mitigating resources). Being a part of business interaction networks allows an organisation to gather knowledge and use expertise more quickly and effectively. In turn, such external support allows an organisation to manage unexpected challenges, respond more appropriately to adverse conditions and recover from misfortune, damage or destabilising perturbation in the environment. External support, thus, can have a positive influence on organisational resilience. Therefore, considering the above, the following hypothesis can be assumed: 
H1c. A relationship exists between external support and organisational resilience.

Appropriate management of stakeholder relationships can bring measurable benefits to an organisation from minimising the risks associated with, e.g. employee strikes, to ideas for great innovation or higher innovativeness obtained despite the lack of sufficient internal resources. To understand relationships and resources, the organisation might need to access other organisations and institutions during potentially disruptive events, which provide a better chance of gaining access to these resources. It must be underlined that external support is only one possible choice among different resources essential for creating organisational resilience. Besides, received support does not guarantee maintained organisational resilience, although the possibility exists. Moreover, it may not only bring results in the form of strengthened organisational resilience and the short-term growth of organisational performance but also can ensure the sustainability and stability of organisational functioning in the long-term perspective by developing solutions that strengthen the organisation's ability to manage the unexpected. In the context of the relationships described above, a need arises to analyse the impact of external support on organisational performance while analysing the mediating role of organisational resilience. It will allow verifying and more comprehensively explaining the mechanism behind the influence of external support on organisational performance. Therefore, a hypothetical model for the impact of external support on organisational performance was assumed, considering the mediating role of organisational resilience, which is clearly connected to both. Therefore, in light of the above, the main hypothesis maintains that:

H2. External support influences the organisational performance (an indirect effect) through organisational resilience (an intermediary variable).

The diagram presented in Fig. 1 illustrates the adopted research hypotheses.

\subsection{CORPORATE REPUTATION AND ITS INFLU- ENCE ON THE SCOPE OF EXTERNAL SUPPORT, ORGANISATIONAL RESILIENCE AND PERFOR- MANCE}

The growing body of research demonstrates that corporate reputation is indicated as a very important intangible resource of a company (Ali et al., 2019; Bergh et al., 2010; Djordjević \& Djukić, 2008; Roberts, 2002), and even considered to be the most important (Pérez-Cornejo et al., 2020; Almeida \& Coelho, 2019; Hall, 1992). The literature provides many definitions of the term, but they are not consistent. The first approach treats corporate reputation as awareness, i.e. the perception of the company's stakeholders, without its simultaneous judgement (Fombrun \& van Riel, 1997). Another is an assessment, where the focus is on the opinion of the company's status (Pharoah, 2003) or assets (Weigelt \& Camerer, 1988) but this approach is criticised for the excessive concentration on the consequences of the phenomenon (Barnett et al., 2006). Considering all the approaches above, the definition by Barnett et al. (2006) seems very apt as it covers all aspects and describes corporate reputation as "observers' collective judgments of a corporation based on assessments of the financial, social, and environmental impacts attributed to the corporation over time" (Barnett et al., 2006, p. 34). Noteworthy is also the definition of a higher degree of generality provided by Pérez-Cornejo et al. (2019), where "corporate reputation is defined as the expectations of various stakeholders regarding the company's ability to satisfy their interests" (Pérez-Cornejo et al., 2019, p. 1252).

Although the literature offers different concept definitions (Šontaitè-Petkevičienè, 2019; Barnett, 2006), researchers seem to agree that corporate reputation is a collective phenomenon as the topic always revolves around a group of people (i.e., stakeholders) (Rindova \& Martins, 2012; Walsh et al., 2009; Cretu $\&$ Brodie, 2007). Thus, there is no doubt that corporate reputation has an immense impact on building

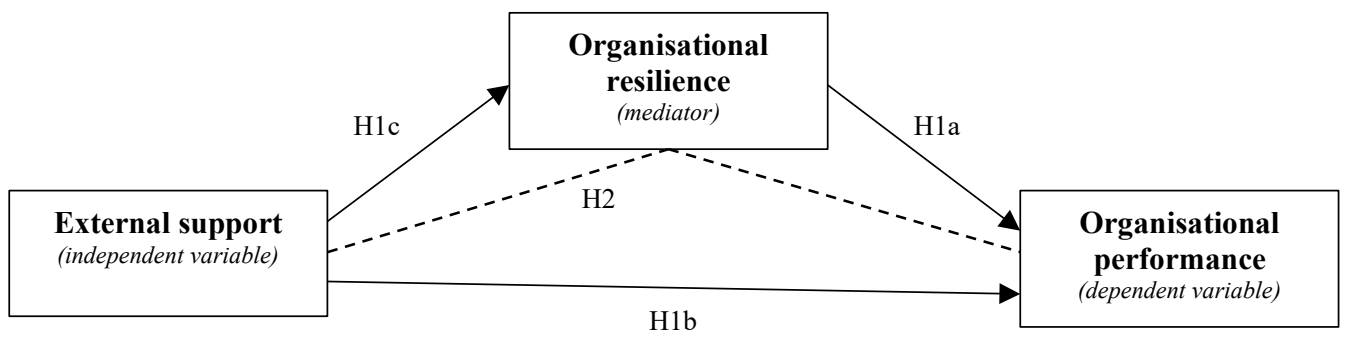

Fig. 1. Influence of external support on the organisational performance through organisational resilience 
the relationship of the company with its stakeholders (Pérez-Cornejo et al., 2020; Bergh et al., 2010), and also allows shaping their desired behaviours (Ali et al., 2019). However, it should be remembered that individual groups of stakeholders have different characteristics and also differ in the nature of their participation in the organisation (Ali et al., 2015; Gabionetta et al., 2007). Therefore, the drivers and benefits of positive corporate reputation are different.

First, good corporate reputation results in a higher level of consumer satisfaction, trust, loyalty, and word-of-mouth (Roberts, 2002; Walsh et al., 2009; Chun, 2005; Fedorko et al., 2017; Szwajca, 2017), and, very importantly, customer value (Cretu \& Brodie, 2007). Therefore, it affects consumer purchasing decisions. Consumers are willing to pay premium prices and are less sensitive to price changes (Burke et al., 2018), which seems crucial because buyers are main creators of the revenue streams (Pérez-Cornejo et al., 2020; Ali, 2011; Walsh et al., 2009). Second, corporate reputation is a factor in achieving sustainable competitive advantage that is difficult to imitate, and, as a consequence, it can become a source of superior profits (Almeida \& Coelho, 2019; Rindova \& Martins, 2012; Bergh et al., 2010; Deephouse, 2000; Hall, 1992; Walsh et al., 2009; Roberts, 2002; Djordjević \& Djukić, 2008). Third, it affects the trust and loyalty of investors (Helm, 2011), suppliers and other contractors (Potgieter, 2018). Fourth, it helps to attract adequate human resources from the labour market, has an impact on positive feelings of employees (Ali et al., 2019; Potgieter, 2018; Bieńkowska et al., 2020), and also reduces the voluntary turnover (Makarius et al., 2017). As a consequence, corporate reputation affects organisational performance (Bergh et al., 2010; Pradhan, 2016) and company value (Almeida \& Coelho, 2019; Roberts, 2002).

Corporate reputation is based on communication processes and personal stakeholder experiences, i.e., as a result of satisfying experiences with a corporate product or service, but also as a result of a broader assessment of employment conditions, investment opportunities and engagement in socially responsible behaviour or financial and competitive performance (Gabionetta et al., 2003). Stakeholders tend to pay special attention to the quality, timeliness, openness and honesty of communication, which seems to contribute substantially to the fair valuation of an organisation's reputation. It is not surprising that behaviours, reactions and decisions of stakeholders are influenced by those factors and, as a consequence, by the subjectively perceived organisation's reputation. They are more willing to support organisations that receive a better evaluation. It is noteworthy that the level of performance is also an important factor to consider during the evaluation of an organisation's reputation. Gabionetta et al. (2003) stated that wellperforming companies are generally regarded as more credible - i.e., healthier and better managed, thus, able to deliver positive results now and in the future - than poorly-performing companies. Reputation increases the organisation's attractiveness for partners, joint ventures and prospective funding sources, leads to lower costs and higher prices, and, as a consequence, the organisation can achieve higher profits (Rhee \& Valdez, 2009).

We can also observe a kind of feedback between external support and organisational performance in the context of corporate reputation. Corporate reputation changes over time. When seeking further external support, organisations must try not to fail the trust of stakeholders. Therefore, they must demonstrate the ability to "use" the offered external support in the best possible way (that can be judged, i.e., by organisational performance), which allows stakeholders to think that they (organisations) thoughtfully "consume" the offered resources. In that context, it seems that the effectiveness of external support and its impact on the overall effectiveness of the organisation could be higher, and reputation (good reputation and the willingness to maintain it as a policy for the future) can be a catalyst for this relationship. Therefore, considering the above, the following hypothesis can be assumed:

H3a. The higher is the corporate reputation, the greater is the influence of external support on organisational performance.

The relationship between corporate reputation and the scope of external support is undisputable. Good reputation conveys the company's overall attractiveness, increases investor confidence and customer trust (Fombrun, 2005). Thus, it induces repeat purchases or encourages potential investors to make additional financial resources available. And vice versa, poor reputation is not conducive to obtaining additional loans or capital contributions. It can, therefore, be concluded that corporate reputation is important for coping, is often emphasised once acquired, and can protect the organisation in the event of a crisis. In situations of an instability or crisis, it can buy some time as it is highly probable that stakeholders, aiming to reduce uncertainty in decision-making processes, would be more likely to base 
their decisions on the perceived reputation of the organisation. Therefore, by developing an appropriate reputation background, an organisation may even escape crises or their harmful consequences (Koronis \& Ponis, 2012) or have more time and space to remedy the problem if crises are unavoidable. As a consequence, it can function successfully despite unfavourable conditions, i.e., survive, ensure business continuity and recovery. Hence, by making external support more accessible, corporate reputation also has the potential to strengthen an organisation's capability to modify negative and inflexible propensities to face unpredicted events better (which is organisational resilience).

This relationship seems to work especially well if crises are not the fault of the organisation. According to Ali et al. (2019), if, e.g., a political action leads to economic instability, reputation can protect against negative effects. The same was observed during the crisis caused by COVID-19 pandemic. In fact, both of these situations did not fully test the reputation of organisations. The origin of crises can be different, and corporate reputation is especially important in the case where the organisation may become the target for blame. Faced with incomplete information about company's actions, stakeholders not only interpret the first-order signals sent by companies but also rely on their previous experience and the evaluative signals refracted by other key stakeholders (Fombrun, 2005). However, Koronis and Ponis (2012, p. 283) stated that "the problem with corporate reputation is that it is solely based on the perceptions and evaluations of the stakeholders that are flux, situational and easy to be changed within a relatively short amount of time". Each crisis should be treated as a potentially reputation-damaging event that can be followed by the rapid erosion of reputation. In such a case, key stakeholders of the organisation may react negatively by lowering their quality of involvement, acting confrontationally towards the management, demanding better contractual terms, and/or detaching from the firm. This translates into difficulties in obtaining new clients and maintaining current ones (Rhee \& Valdez, 2009), which together significantly reduces the ability to handle difficult situations (organisational resilience).

In summary, by strengthening the network connections with other stakeholders, corporate reputation has an impact on "valorising businesses" in a competitive environment, especially in the context of, e.g., economic downturns, because stakeholders share the view that it contributes to a healthier (more resilient) business (Andres \& Rounds, 2015). It is for sure not the main, direct and certainly not the only factor influencing organisational resilience. However, attracting stakeholder interest helps to keep market opportunities and make available new resources to manage uncertainty and develop, which certainly can lead to the strengthening of organisational resilience. Nevertheless, it should be treated as a catalyst rather than a direct factor shaping organisational resilience. Therefore, the following hypothesis is offered: $\mathrm{H} 3 \mathrm{~b}$. The higher is the corporate reputation, the greater is the influence of external support on organisational resilience.

As mentioned above, corporate reputation is linked with organisational performance (Rindova \& Martins, 2012; Bergh et al., 2010). According to Tracey and French (2017, p. 57), "firms with superior reputations have a greater capacity to increase prices, retain customers, attract higher quality managers and employees, as well as more committed investors and capable strategic partners". Most research on the topic points to the direct effect between these constructs (Roberts \& Dowling, 2002). However, there is some doubt regarding indirect influence (Tracey \& French, 2017).

The relationship between corporate reputation and organisational resilience is also indisputable. Favourable reputation is treated as an excellent resource in the times of crisis (Coombs \& Holladay, 2006). In addition, research showed that companies with a good reputation could maintain it even in the event of difficulties during a crisis (Fombrun \& van Riel, 2003) as reputation protects company assets against damage caused by the crisis (Coombs \& Holladay, 2006). According to Jones et al. (2000), corporate reputation protects against adverse events in a competitive environment, which can affect organisational performance. Roberts and Dowling (2002) believed that appropriate management of corporate reputation allows repairing or avoiding damage resulting from disruptive events. This means that a superior level of reputation not only helps to mitigate negative consequences but also avoid crises (Tracey \& French, 2017), which in turn leads to secured results of the organisation. Therefore, the following hypothesis appears to be valid:

$\mathrm{H} 3 \mathrm{c}$. The higher is the corporate reputation, the greater is the influence of organisational resilience on organisational performance.

In the context of the proposed mediation model, hypotheses $\mathrm{H} 3 \mathrm{~b}$ and $\mathrm{H} 3 \mathrm{c}$ could be summarised as one statement, namely: the better is the corporate 
reputation, the stronger is the influence of external support on organisational performance through organisational resilience. Fig. 2 presents the diagram illustrating the adopted research hypotheses.

\section{Research Methodology}

Aiming to verify the proposed mediation model and its moderator, quantitative research was conducted. The choice of the survey method was influenced by the possibility to cover a larger number of research respondents. The anonymity ensured by the questionnaire surveys to the respondents had an effect on the number of answers obtained. This approach allowed for a quantitative description of the state of the studied phenomena and for determining the nature and intensity of connections between them. A questionnaire designed by the authors was used as the basic research tool. The main survey was conducted in December 2019, among employees of organisations located in Poland (one employee per organisation was always tested; respondents belonged to senior management). The country of origin was the only condition limiting the sample obtained from the panel of respondents from SurveyMonkey. The sampling was purposive.

In summary, the research sample contained employees of organisations operating in Poland. In total, 268 responses were collected. The sample was sufficiently diversified (considering the diversity of organisational characteristics) to serve as a basis for general conclusions concerning the given topic. Table 1 presents the characteristics of the sample, which indicate that the sample covered a diverse group of organisations. Due to the lack of data, the number in distinct cross-sections of the research sample is different.

\subsection{OVERVIEW OF VARIABLES}

The hypotheses verification was based on four key variables: corporate reputation, external support, organisational resilience, and organisational performance.

Corporate reputation was measured based on the concept by Ali et al. (2019). The scale contained eight items, which were assessed based on a 5-point Likert scale (from "I strongly disagree" to "I strongly agree" with the middle point "I have no opinion").

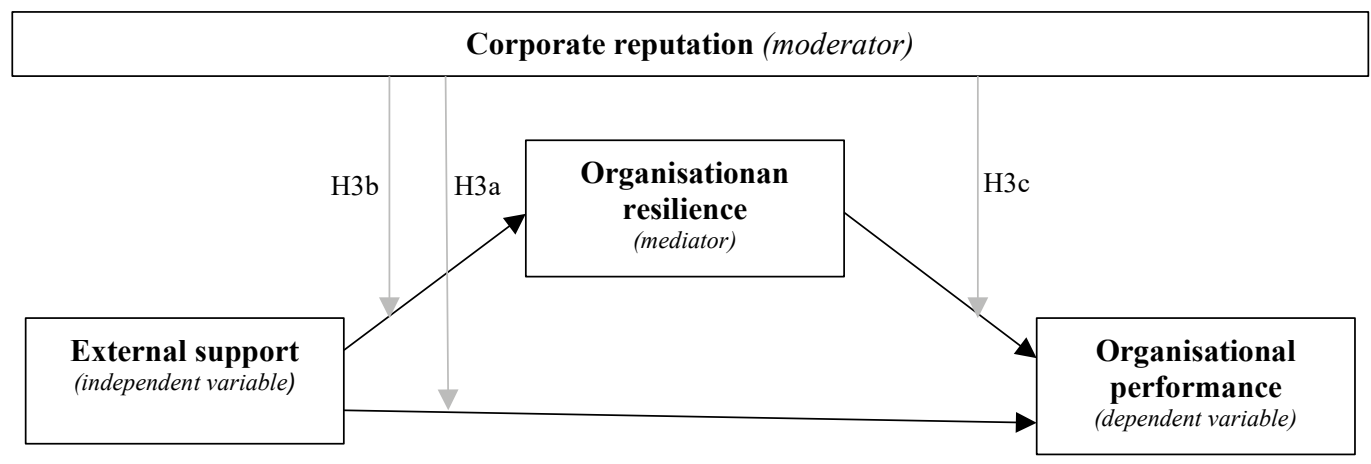

Fig. 2. Model for the influence made by external support on the organisational performance through the organisational resilience and the moderating role of corporate reputation

Tab. 1. Research sample characteristic

\begin{tabular}{|c|c|c|c|c|}
\hline AGE OF THE ORGANISATION & $\begin{array}{l}\text { MANUFACTURING } \\
\text { ORGANISATIONS }\end{array}$ & $\begin{array}{c}\text { TRADE } \\
\text { ORGANISATIONS }\end{array}$ & $\begin{array}{c}\text { SERVICE } \\
\text { ORGANISATIONS }\end{array}$ & TOTAL \\
\hline less than a year in the market & 16 & 7 & 2 & 25 \\
\hline $1-5$ years in the market & 43 & 20 & 14 & 77 \\
\hline $5-20$ years in the market & 47 & 25 & 33 & 105 \\
\hline more than 20 years in the market & 22 & 10 & 23 & 55 \\
\hline Total & 128 & 62 & 72 & 262 \\
\hline serving local markets & 67 & 39 & 45 & 151 \\
\hline serving global markets & 55 & 20 & 27 & 102 \\
\hline Total & 122 & 59 & 72 & 253 \\
\hline
\end{tabular}


External support in an organisation was measured based on a 5-point Likert scale (from "I strongly disagree" to "I strongly agree" with the middle point "I have no opinion"). There were six items in this scale, referring to the range of the organisation's collaboration with and outside the industry, the intensity of networking and accessibility to external resources. The questions were phrased based on the available literature (Lee et al., 2013; Seville, 2017; McCann et al., 2009; Tengblad \& Oudhuis, 2018).

The variable organisational resilience was built based on four properties assigned to system resilience: robustness, redundancy, resourcefulness and rapidity (Bruneau et al., 2003; Wicker et al., 2013). Within the four properties, four measures (one for each property) were indicated for organisational resilience. They were rated on a 5-point Likert scale (from "I strongly disagree" to "I strongly agree" with the middle point "I have no opinion").

The Balanced Scorecard concept by Kaplan and Norton (1996) was used to build the variable organisational performance. Within four perspectives (financial performance, internal business processes, customer perspectives, and innovation and learning), ten measures were indicated for organisational performance. They were rated on a 5-point Likert scale (from well below expectations to well above expectations with the middle point being equal to what expected).

\subsection{DESCRIPTIVE STATISTICS AND THE RELI- ABILITY ANALYSIS OF SCALES}

Cronbach's alpha was used to estimate the internal consistency of responses. Table 2 presents the results. The Cronbach's a was high for corporate reputation, external support, organisational resilience and organisational performance, indicating high internal reliability of the scales and measurements.

\section{RESEARCH RESULTS}

The analysis of research results was carried out in two steps, which was the pattern of moderation of the mediation model developed by Bieńkowska et al. (2019). As a first step, the mediation model was built and verified. Then, the moderator in the previously built mediation model was introduced, and the built model was verified.

\subsection{Mediation MOdel}

As mentioned before, the first step of the research was to build the mediation model. Three conditions must be met to establish such a model:

- the independent variables must be related to the mediator,

- the dependent variables must be related to the mediator, and

- a significant relationship between the independent variables and dependent variables should be reduced (partial mediation) or no longer be significant (full mediation) when controlling for the mediator (Baron \& Kenny, 1986).

Aiming to verify the first two conditions and hypotheses H1a, H1b, H1c, the r-Pearson's correlation analysis was performed. The results are presented in Table 3.

The obtained results showed a statistically significant, positive and high or moderate correlation between all analysed variables. It must be pointed out that this correlation is definitely the lowest (but still moderate) in the case of the relationship between external support and organisational performance. It allows for the acceptance of $\mathrm{H} 1 \mathrm{a}, \mathrm{H} 1 \mathrm{~b}$ and $\mathrm{Hlc}$ hypotheses.

Therefore, such a conclusion enabled to verify the mediating model of organisational performance. To do that, the mediation model was built for external support as an independent variable, and organisational performance as a dependent variable. Organisational resilience was tested as the mediator in the model. The calculations were made using the Process macro for SPSS Version 3.4 by Andrew F. Hayes. To confirm the assumed relationship, it was supposed that the obtained regression model was statistically significant and the total effect was higher than the direct effect calculated for the given variables. Table 4 presents the results of the analysis.

Tab. 2. Defined variables and the results ofthe reliability analysis of scales

\begin{tabular}{|c|l|r|r|r|r|r|}
\hline No. & \multicolumn{1}{|c|}{ Variable } & No. Of SCALES & \multicolumn{1}{c|}{ CrONBACH'S A } & FACtOR ANAlysis (\%) & M & SD \\
\hline 1 & Corporate reputation & 8 & 0.871 & 52.625 & 3.51 & 0.76 \\
\hline 2 & External support & 6 & 0.824 & 53.313 & 3.42 & 0.95 \\
\hline 3 & Organisational resilience & 4 & 0.809 & 63.659 & 3.29 & 0.87 \\
\hline 4 & Organisational performance & 10 & 0.873 & 46.817 & 3.41 & 0.69 \\
\hline
\end{tabular}


Tab. 3. Correlation analysis of analysed variables

\begin{tabular}{|c|c|c|c|c|}
\hline & & $\begin{array}{l}\text { ORGANISATIONAL } \\
\text { RESILIENCE }\end{array}$ & $\begin{array}{l}\text { EXTERNAL } \\
\text { SUPPORT }\end{array}$ & $\begin{array}{l}\text { CORPORATE } \\
\text { REPUTATION }\end{array}$ \\
\hline \multirow{3}{*}{ External support } & $r$ & $0.549 * *$ & 1 & \\
\hline & Sig. & 0.000 & - & \\
\hline & $\mathrm{N}$ & 256 & 262 & \\
\hline \multirow{3}{*}{ Corporate reputation } & $r$ & $0.606^{* *}$ & $0.570 * *$ & 1 \\
\hline & Sig. & 0.000 & 0.000 & - \\
\hline & $\mathrm{N}$ & 249 & 253 & 255 \\
\hline \multirow{3}{*}{$\begin{array}{l}\text { Organisational perfor- } \\
\text { mance }\end{array}$} & r & $0.541^{* *}$ & $0.484 * *$ & $0.590^{* *}$ \\
\hline & Sig. & 0.000 & 0.000 & 0.000 \\
\hline & $\mathrm{N}$ & 247 & 251 & 246 \\
\hline
\end{tabular}

Tab. 4. Organisational resilience as the mediator of the relationship between external support and organisational performance

\begin{tabular}{|c|r|r|r|r|r|}
\hline MEDIATOR & $\begin{array}{c}\text { DIRECT EFFECT } \\
\text { VALUE }\end{array}$ & $\begin{array}{c}\text { INDIRECT EFFECT } \\
\text { VALUE }\end{array}$ & BOOT LLCI & BOOT ULCI & R2 \\
\hline Organisational resilience & 0.2012 & 0.1568 & 0.0994 & 0.2217 & 0.3467 \\
\hline
\end{tabular}

*accepted level of significance 0.05

The obtained research results showed that the built regression model with the mediator was valid and statistically significant $(\mathrm{F}(2,245)=64.224$, $\mathrm{R} 2=0.347$ ). Furthermore, organisational resilience was a statistically significant mediator of the model $(\mathrm{p}<0.001$, coeff. $=0.3238$, se $=0.0506)$. According to Table 4, the mediating effect (the indirect effect of the independent variable on the dependent variable through the mediator variable) is also statistically significant (BootLLCI $=0.099$ and BootULCI $=0.222$ and they are both above 0 ), although this is a partial mediation. To confirm it, the Sobel test was calculated $(\mathrm{Z}=5.43, \mathrm{p}<0.001)$, which confirmed that organisational resilience significantly carries the influence of an independent variable to a dependent variable. The obtained model showed that organisational resilience was a partial but significant mediator of the relationship between external support and organisational performance. Therefore, hypothesis $\mathrm{H} 2$ can be accepted.

\subsection{MODERATOR ANALYSIS FOR THE CORPO- RATE REPUTATION}

As a next step of the analysis, the obtained mediation model was studied in the context of corporate reputation to verify the statistical significance of it as moderator of the relationships given in the model. As the first step, to check if corporate reputation has a potential to be a moderator of the discussed relationships, the hypotheses were tested using the regression analysis with the moderator for three separate sets of independent relationships:

- corporate reputation as the moderator of the relationship between external support and organisational performance,

- corporate reputation as the moderator of the relationship between external support and organisational resilience,

- corporate reputation as the moderator of the relationship between organisational resilience and organisational performance.

In the next step, this variable was tested as the moderator in the previously build mediation model (as a moderator of the relationship between external support and organisational performance trough organisational resilience) to test hypotheses H3a, $\mathrm{H} 3 \mathrm{~b}$ and $\mathrm{H} 3 \mathrm{c}$. In both cases, the moderated regression analysis procedure was performed using the Process macro for IBM SPSS Statistics. The results of the analysis are presented in Table 5 .

Based on research results, when the discussed relationships are treated separately, corporate reputation is the moderator for all of them (all obtained results were statistically significant, Table 5). However, the obtained results showed that in the proposed mediation model, corporate reputation moderated the path from external support to organisational resilience (the moderator coeff. $=0.108, \mathrm{p}=0.0222$ ) and the path from organisational resilience to organi- 
Tab. 5. Regression model statistics

\begin{tabular}{|c|c|c|c|c|c|c|}
\hline MODEL DESCRIPTION & $\mathbf{R}^{2}$ & DeLtA $\mathbf{R}^{2}$ & $\begin{array}{l}\text { MODERATOR } \\
\text { COEFF. }\end{array}$ & $\begin{array}{l}\text { STANDARD } \\
\text { ERROR }\end{array}$ & T STAT & P Value \\
\hline \multicolumn{7}{|l|}{ Separate relationship } \\
\hline $\begin{array}{l}\text { External support } \\
\text { Moderator } \\
\text { dependent v.: org. performance }\end{array}$ & 0.422 & 0.030 & 0.135 & 0.038 & 3.547 & $0.0005^{*}$ \\
\hline $\begin{array}{l}\text { External support } \\
\text { Moderator } \\
\text { dependent v.: org. resilience }\end{array}$ & 0.451 & 0.012 & 0.106 & 0.046 & 2.281 & $0.0234^{*}$ \\
\hline $\begin{array}{l}\text { Organisational resilience } \\
\text { Moderator } \\
\text { dependent v.: org. performance }\end{array}$ & 0.456 & 0.049 & 0.179 & 0.039 & 4.609 & $0.0000^{*}$ \\
\hline \multicolumn{7}{|c|}{ Mediation model } \\
\hline $\begin{array}{l}\text { External support } \\
\text { Corporate reputation } \\
\text { Moderator } \\
\text { dependent v.: organisational resilience }\end{array}$ & 0.441 & 0.013 & 0.108 & 0.047 & 2.302 & $0.0222^{*}$ \\
\hline $\begin{array}{l}\text { External support } \\
\text { Organisational resilience } \\
\text { Corporate reputation } \\
\text { Moderator } 1 \text { (Ext.Supp x Corp.Rep) } \\
\text { Moderator } 2 \text { (Org.Res x Corp.Rep) } \\
\text { dependent v.: Org. performance }\end{array}$ & 0.472 & $\begin{array}{l}0.001 \\
0.023\end{array}$ & $\begin{array}{r}-0.031 \\
0.196\end{array}$ & $\begin{array}{l}0.059 \\
0.062\end{array}$ & $\begin{array}{r}-0.515 \\
3.180\end{array}$ & $\begin{array}{r}0.6068 \\
0.0017^{*}\end{array}$ \\
\hline
\end{tabular}

sational performance (the moderator coeff. $=0.196$, $\mathrm{p}=0.0017$ ), but not the path from external support to organisational performance (the moderator coeff.= $-0.031, \mathrm{p}=0.6068$ ). Hence, corporate reputation is a statistically significant moderator in the case of both relationships, i.e., between external support and organisational resilience $(F(3,235)=61.897, p<0.001)$ and the relationship between organisational resilience and organisational performance $(\mathrm{F}(4,234)=52.106, \mathrm{p}$ $<0.001)$. Therefore, as shown in Table 5 , the obtained results are the basis for the acceptance of hypotheses $\mathrm{H} 3 \mathrm{~b}$ and $\mathrm{H} 3 \mathrm{c}$ and the rejection of the hypothesis $\mathrm{H} 3 \mathrm{a}$.

\section{Discussion}

The role of organisational resilience in shaping organisational performance seems to be a significant issue in the management of modern organisations. In this context, the main focus of the study was to explain how external support and corporate reputation affected the results of organisation's functioning and, in particular, the aim of the paper was to clarify the mechanism behind the moderating role of corporate reputation in the influence of external support on organisational performance, considering the mediat- ing role of organisational resilience. The obtained results are given in Fig. 3.

To achieve the research goal, it was first necessary to demonstrate the influence of external support on organisational performance, which was suggested by Mambula (2004), Cheah et al. (2019) and others. The results confirmed the anticipated relationship. In addition, it was noted that the relationship between these constructs was indirect. Organisational resilience proved to be a mediator for shaping the relationship between external support and organisational performance. According to Tengblad and Oudhuis (2018) or McCann et al. (2009), external support plays a fundamental and direct role in shaping organisational resilience. In addition, organisational resilience directly influences organisational performance, which is consistent with the statements by Carden et al. (2018) or Sundström and Hollnagel (2006). In the above context, the model of external support and organisational performance through the organisation's resilience can be considered validated.

Then, an issue of corporate reputation was introduced to the above considerations. Corporate reputation is the moderator in the mediation model and affects both paths that constitute the indirect effect of external support on organisational performance 


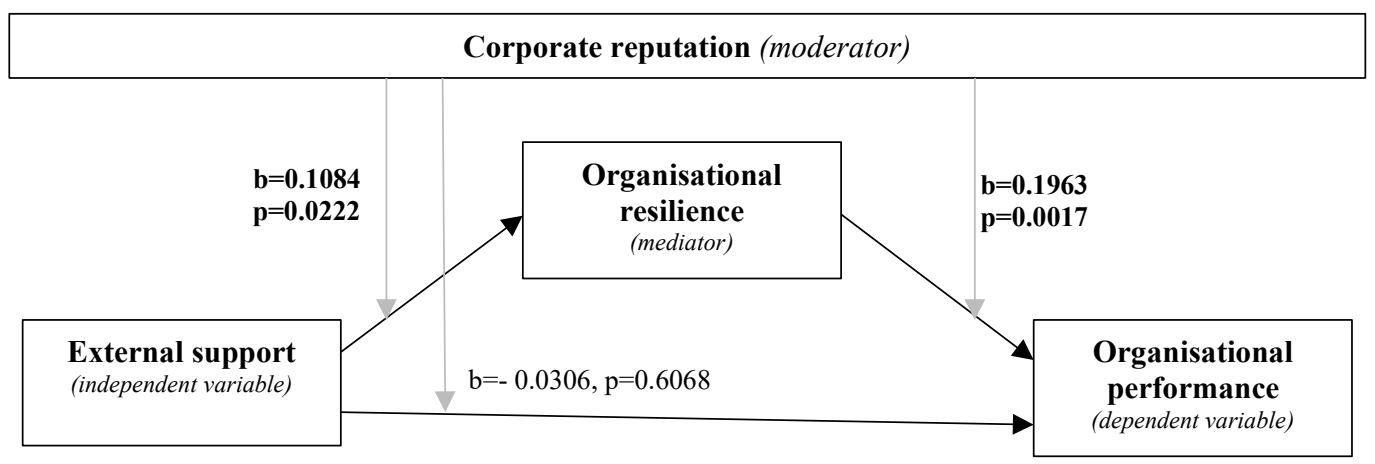

Fig. 3. Results of moderating effects in the mediation model

through organisational resilience. The obtained results did not confirm all of the adopted assumptions.

According to the model, corporate reputation moderates the relationship between corporate reputation and organisational performance most strongly. This means that for organisations with a superior reputation, even a slight improvement in organisational resilience would result in improved organisational performance. These findings appear to be consistent with conclusions by Jones et al. (2000), Roberts and Dowling (2002), Tracey and French (2017). The moderating role of corporate reputation was also confirmed in the relationship between external support and organisational resilience. This means that for organisations with a superior reputation, even a small increase in external support would positively impact organisational resilience. This finding coincides with the settlement by Andres and Rounds (2015).

However, it is worth noting the interesting relationship that appeared in the presented mediation model. The research did not confirm the assumption about corporate reputation being the moderator in the relationship between external support and organisational performance. The relationship between constructs was negative, although statistically insignificant). This phenomenon can be explained by the fact that enterprises with a superior reputation might be ignored in the case of support that is not uniform for all entities. This finding seems to be confirmed by Fombrun (2012), who believed that reputation could be transformed into stakeholder support or the lack of support, resulting in different levels of resource acquisition and, consequently, different levels of organisational performance. In addition, it seems that enterprises that cannot be supported by external resources focus more on their own resources, which leads to improving organisational performance. Therefore, they try to improve profitability in other ways, for example, by launching innovative processes. However, the above statements require confirmation in empirical research. When making the analysis, it would be worth considering types of support suggested by Cheah et al. (2019), i.e. the type of support provided (direct and indirect) and types of stakeholder (e.g., government, private or non-profit) as, for example, institutional support depends on meeting formal conditions rather than corporate reputation.

\section{CONCLUSION}

Corporate reputation is nowadays treated as an intangible asset of an organisation, which is rather measurable. It helps to distinguish an organisation in the market and build a dialogue and exchange resources with stakeholders. According to Sirgy (2002, p. 145), effective exchange with external stakeholders is the condition of survival and growth of organisations. It benefits both the organisation and its stakeholders, can be considered at many levels (institutional and non-institutional, contractual or with no intentions to contract, etc.) and concern the flow of a wide variety of resources, either tangible (i.e., money, services, employees or specific skills) or intangible, although no less important (i.e., information, influences, social support or prestige). It should also be noted that relationships with internal stakeholders matter at least as much; however, this paper focused on relationships with external stakeholders and, more precisely, on the support they can give organisations, especially in the face of hardship. The performed literature analysis resulted in a conclusion that corporate reputation could be a moderator of a relationship between external support and organisational resilience and organisational performance. The obtained results clearly showed a positive and statistically significant correlation between all discussed 
variables. Moreover, on the basis of the conducted empirical research, the moderating effect of corporate reputation was found in the mediation model for the influence made by external support on organisational performance through organisational resilience.

The obtained results imply specific practical recommendations. Since corporate reputation can be the key to achieving greater organisational resilience and performance, organisations should especially focus on the management of this category. According to stakeholder theory, the moral obligation to maintain mutually appropriate and beneficial relationships with stakeholders usually belongs to managers, who should consider relationships with stakeholders in the context of strategic management processes to maximise the organisational benefits. It is not an easy task as different stakeholders influence organisations in different ways, some more than others. Thus, the task requires many different approaches and actions. According to Friedman \& Miles (2002), relationships between organisations and stakeholders change over time. However, the efforts pay off in the event of a crisis.

The presented empirical study has some limitations. The obtained sample size (268 organisations) is not representative by far. Besides, it was verified in one business context only, so in future, it is worthwhile to consider verifying the formulated hypotheses in organisations operating in other countries. However, the shown diversity of the sample appeared sufficient to form some general conclusions based on the obtained results. The obtained results constitute a solid first step in the analysis of the role played by the influence of corporate reputation on the scope of external support and its impact on organisational performance through organisational resilience. However, further research is required as well as in-depth analysis to provide further recommendations for the management of organisational resilience. Moreover, the obtained conclusions allowed formulating directions for future research. There is a need for further analysis concerning the type of support (institutional, non-institutional) and types of stakeholders with a special focus on the internal ones. The support given by employees in shaping organisational resilience and organisational performance can have immense importance. Therefore, employees as internal stakeholders seem to be an important group (that was intentionally omitted in the present research), which influences corporate reputation and is influenced by it.

\section{LITERATURE}

Ali, I. (2011). Influence of corporate social responsibility on development of corporate reputation and customer purchase intentions. Romanian Review of Social Sciences, 1, 1-8.

Ali, I., Ali, M., Grigore, G., Molewoth, M., \& Jin, Z. (2019). The moderating role of corporate reputation and employee-company identification on the work-related outcomes of job insecurity resulting from workforce localization policies. Journal of Business Research, 117, 825-838. doi: 10.1016/j.jbusres.2019.02.060

Ali, R., Lynch, R., Melewar, T. C., \& Jin, Z. (2015). The moderating influences on the relationship of corporate reputation with its antecedents and consequences: A meta-analytic review. Journal of Business Research, 68(5), 1105-1117. doi: 10.1016/j.jbusres.2014.10.013

Almeida, M. da G. M. C., \& Coelho, A. F. M. (2019). The antecedents of corporate reputation and image and their impacts on employee commitment and performance: the moderating role of CSR. Corporate Reputation Review, 22(1), 10-25. doi: 10.1057/s41299018-0053-8

Andres, L., \& Round, J. (2015). The creative economy in a context of transition: A review of the mechanisms of micro-resilience. Cities, 45, 1-6. doi: 10.1016/j.cities.2015.02.003

Bala Subrahmanya, M. H. (2013). External support, innovation and economic performance: what firm level factors matter for high-tech SMEs? How? International Journal of Innovation Management (IJIM), 17(05), 1-26. doi: 10.1142/S1363919613500242

Barnett, M. L., Jemier, J. B., \& Lafferty, B. A. (2006). Corporate Reputation: The Definitional Landscape. Corporate Reputation Review, 9(1), 26-38. doi: 10.1057/ palgrave.crr.1550012

Baron, R. M., \& Kenny, D. A. (1986). The moderator-mediator variable distinction in social psychological research: Conceptual, strategic, and statistical considerations. Journal of Personality and Social Psychology, 51(6), 1173-1182. doi: 10.1037/0022-3514.51.6.1173

Bergh, D. D., Ketchen Jr., D. J., Boyd, B. K., \& Bergh, J. (2010). New frontiers of the reputation-performance relationship: Insights from multiple theories. Journal of Management, 36(3), 620-632. doi: $10.1177 / 0149206309355320$

Bieńkowska, A., Tworek, K., \& Zabłocka-Kluczka, A. (2019). Moderating role of UX and IT reliability in controlling influence on job performance and organizational performance. Raporty Wydziału Informatyki i Zarządzania Politechniki Wrocławskiej, PRE(9).

Bieńkowska, A., Sałamacha, A., \& Tworek, K. (2020). The role of employees in shaping brand performance. Forum Scientiae Oeconomia, 8(2), 93-107. doi: 10.23762/FSO_VOL8_NO2_6

Bird, B. (1988). Implementing entrepreneurial ideas: The case for intention. Academy of Management Review, 13(3), 442-453. doi: 10.5465/amr.1988.4306970

Bruneau, M., Chang, S. E., Eguchi, R. T., Lee, G. C., O'Rourke, T. D., Reinhorn, A. M., \& von Winterfeldt, D. (2003). A framework to quantitatively 
assess and enhance the seismic resilience of communities. Earthquake Spectra, 19(4), 733-752. doi: $10.1193 / 1.1623497$

Burke, P. F., Dowling, G., \& Wei, E. (2018). The relative impact of corporate reputation on consumer choice: beyond a halo effect. Journal of Marketing Management, 34(13-14), 1227-1257. doi: 10.1080/0267257X.2018.1546765

Carden, L. L., Maldonado, T., \& Boyd, O. R. (2018). Organizational resilience: A look at McDonald's in the fast food industry. Organizational Dynamic, 47, 25-31. doi: 10.1016/j.orgdyn.2017.07.002

Carey, P. J. (2015). External accountants' business advice and SME performance. Pacific Accounting Review, 27(2), 166-188. doi: 10.1108/PAR-04-2013-0020

Cook, P. (2001). Finance and Small and Medium-Sized Enterprise in Developing Countries. Journal of Development Entrepreneurship, 6(1), 17-24. doi: 10.5539/ ijbm.v8n14p36

Coombs, W. T., \& Holladay, S. J. (2006). Unpacking the halo effect: reputation and crisis management. Journal of Communication Management, 10(2), 123-137. doi: $10.1108 / 13632540610664698$

Cretu A., \& Bordie R. J. (2007). The influence of brand image and company reputation where manufacturers market to small firms: A customer value perspective. Industrial Marketing Management, 36, 230-240. doi: 10.1016/j.indmarman.2005.08.013

Deephouse, D. L. (2000). Media reputation as a strategic resource: An integration of mass communication and resource-based theories. Journal of Management, 26(6), 1091-1112. doi: 10.1177/014920630002600602

Dewalska-Opitek, A. \& Mitręga, M. (2019). Appreciate me and $\mathrm{i}$ will be your good soldier. The exploration of antecedents to consumer citizenship. Engineering Management in Production and Service, 11(3), 48-59. doi: 10.2478/emj-2019-002

Djordjević, B., \& Djukić, S. (2008). The impact of downsizing on the corporate reputation. Facta Universitatis Series: Economics and Organization, 5(1), 51-62.

Fedorko, R., Bačík, R., \& Kerulová, V. (2017). The analysis on the importance of the reputation management in relation to e-commerce subjects. Polish Journal of Management Studies, 15(1), 48-56. doi: 10.17512/ pjms.2017.15.1.05

Fombrun, C. J. (2005). The leadership challenge: building resilient corporate reputations. In J. P. Doh \& S. A. Stumpf (Eds.), Handbook on Responsible Leadership and Governance in Global Business (pp. 54-68). Cheltenham, UK, Northampton, MA, USA: Edward Elgar.

Fombrun, C. J. (2012). The building blocks of corporate reputation: definitions, antecedents, consequences. In M. L. Barnett \& T. G. Pollock (Eds.), The Oxford Handbook of Corporate Reputation, (pp. 94-113). Oxford: Oxford University Press.

Fombrun, C. J., \& van Riel, C. B. M. (1997). The Reputational Landscape. Corporate Reputation Review, 1(12), 5-13. doi: 10.1057/palgrave.crr.1540024

Friedman, A. L., \& Miles, S. (2002). Developing stakeholder theory. Journal of Management Studies, 39(1), 1-21. doi: 10.1111/1467-6486.00280
Gabionetta, C., Ravasi, D., \& Mazzola, P. (2007). Exploring the Drivers of Corporate Reputation: A Study of Italian Securities Analysts. Corporate Reputation Review, 10, 99-123. doi: 10.1057/palgrave.crr.1550048

Gnyawali, D. R., \& Fogel, D. S. (1994). Environments for entrepreneurship development: key dimensions and research implications. Entrepreneurship Theory and Practice, 18(4), 43-62. doi: $10.1177 / 104225879401800403$

Hall R. (1992). The Strategic Analysis of Intangible Resources, Strategic Management Journal, 13(2), 135144.

Hamel, G., \& Välikangas, L. (2002). The quest for resilience. Harvard Business Review, 81(9), 52-63.

Helm S. (2011). Employees' awareness of their impact on corporate reputation. Journal of Business Research, 64, 657-663. doi: 10.1016/j.jbusres.2010.09.001

Cheah, J. C., Amran, A., \& Yahya, S. B. (2019). External oriented resources and social enterprises' performance: The dominant mediating role of formal business planning. Journal of Cleaner Production, 236, 117693. doi: 10.1016/j.jclepro.2019.117693

Chun, R. (2005). Corporate Reputation: Meaning and Measurement. International Journal of Management Reviews, 7(2), 91-109. doi: 10.1111/j.14682370.2005.00109.x

Jones, G., Jones, B., \& Little, P. (2000). Reputation as reservoir: Buffering against loss in times of economic crisis. Corporate Reputation Review, 3(1), 21-29. doi: 10.1057/palgrave.crr.1540096

Kantur, D., \& Iseri-Say, A. (2015). Measuring organizational resilience: a scale development. Journal of Business, Economics and Finance, 4(3), 456-472. doi: 10.17261/ Presacademia.2015313066.

Kaplan, R. S., \& Norton, D. P. (1996). The balanced scorecard: translating strategy into action. Boston: Harvard Business School Press. doi: 10.1016/s07376782(97)89410-6

Koronis, E., \& Ponis, S. T. (2012). Introducing Corporate Reputation Continuity To Support Organizational Resilience Against Crises, The Journal of Applied Business Research, 28(2), 283-290. doi: 10.19030/jabr. v28i2.6850

Koronis, E., \& Ponis, S. T. (2018). Better than before: the resilient organization in crisis mode. Journal of Business Strategy, 39(1), 32-42. doi: 10.1108/JBS-102016-0124.

Lee, A. V., Vargo, J., \& Seville, E. (2013). Developing a Tool to Measure and Compare Organization's Resilience. Natural Hazards Review, 14(1), 29-41. doi: 10.1061/ (ASCE)NH.1527-6996.0000075

Lengnick-Hall, C., Beck, T., \& Lengnick-Hall, M. (2011). Developing a capacity for organizational resilience through strategic human resource management. $\mathrm{Hu}$ man Resource Management Review, 21, 243-255.

Linnenluecke, M. K. (2017). Resilience in Business and Management Research: A Review of Influential Publications and a Research Agenda. International Journal of Management Reviews, 19(1), 4-30. doi: 10.1111/ijmr.12076.

MacMahon, R. (2001). Growth Performance of Manufacturing SMEs; The Influence of Financial Management 
Characteristics. International Small Business Journal, 19(3), 10-19. doi: 10.1177/0266242601193001

Makarius, E. E., Stevens C. E., \& Tenhiälä A. (2017). Tether or Stepping Stone? The Relationship between Perceived External Reputation and Collective Voluntary Turnover Rates. Organization Studies, 38(12), 16651686. doi: $10.1177 / 0170840617693269$

Mambula, C. J. (2004). Relating External Support, Business Growth \& Creating Strategies for Survival: A Comparative Case Study Analyses of Small Manufacturing Firms (SMFs) and Entrepreneurs. Small Business Economics, 22, 83-109. doi: 10.1023/B:SBEJ.0000014450.16699.c6

Manyena, S. B. (2006). The Concept of Resilience Revisited. Disasters, 30, 433-450. http://dx.doi.org/10.1111/ j.0361-3666.2006.00331.x

McCann, J., Selsky, J., \& Lee, J. (2009). Building Agility, Resilience and Performance in Turbulent Environments, People \& Strategy, 32(3), 44-51.

Mitroff, I. I., Pauchant, T. C., Finney, M., \& Pearson, C. (1989). Do (Some) Organisations Cause Their Own Crises? The Cultural Profiles of Crisis-Prone Vs. Crisis-Prepared Organisations. Industrial Crisis Quarter$l y, 3(4), 269-283$. doi: 10.1177/108602668900300401

Mitroff, I.I. (2005). From my perspective: Lessons from9/11: Are companies better prepared today?. Technological Forecasting \& Social Change, 72(3), 375-376.

Norris, F., Stevens, S., Pfefferbaum, B., Wyche, K., \& Pfefferbaum, R. (2008). Community Resilience as a Metaphor, Theory, Set of Capacities, and Strategy for Disaster Readiness. American Journal of Community Psychology, 41(1), 127-150. doi: 10.1007/s10464-0079156-6

Pérez-Cornejo, C., de Quevedo-Puente E., \& DelgadoGarcía, J. B. (2019). Reporting as a booster of the corporate social performance effect on corporate reputation. Corporate Social Responsibility and Environmental Management, 27, 1252-1263. doi: 10.1002/ csr. 1881

Pharoah, A. (2003). Corporate reputation: The boardroom challenge. Corporate Governance, 3(4), 46-51. doi: 10.1108/14720700310497113

Pirotti, G. A., \& Venzin, M. (2017). Resilient Organizations. Responsible Leadership in Times of Uncertainty. Cambridge University Press.

Potgieter, A., \& Doubell, M. (2018). Employer branding as a strategic corporate reputation management tool. African Journal of Business and Economic Research, 13(1), 135-155. doi: 10.31920/Employer_Branding_as_a_Strategic

Pradhan, S. (2016). Impact of corporate social responsibility intensity on corporate reputation and financial performance of Indian firms. Business: Theory and Practice, 17(4), 371-380. doi: 10.3846/btp.17.11123

Rhee, M., \& Valdez, M. E. (2009). Contextual factors surrounding reputation damage with potential Implications for reputation repair. Academy of Management Review, 34, 146-168. doi: 10.5465/amr.2009.35713324

Rindova, V. P., \& Martins, L. L. (2012). Show me the money: a multidimensional perspective on reputation as an intangible asset. In: M. L. Barnett, \& T. G. Pollock (Eds.), The Oxford handbook of corporate reputations (pp. 16-33). Oxford: Oxford University Press.

Roberts, P. W., \& Dowling G. R. (2002). Corporate reputation and sustained superior financial performance. Strategic Management Journal, 23, 1077-1093. doi: 10.1002/smj.274

Seville, E. (2017). Resilient organizations. How to survive, thrive and create opportunities through crisis and change, London, Philadelphia, New Delhi: Kogan Page.

Scholl, H., \& Patin, B. (2012). Resilient Information Infrastructures: Mobilizing Adaptive Capacities under Extreme Events. AMCIS 2012 Proceedings. Retrieved from http://aisel.aisnet.org/amcis2012/proceedings/ EGovernment/6

Sirgy, M. J. (2002). Measuring corporate performance by building on the stakeholders model of business ethics. Journal of Business Ethics, 35(3), 143-162. doi: 10.1023/A:1013856421897

Sundström, G. A., \& Hollnagel, E. (2006). On The Art of Creating and Managing Policies: Facilitating the Emergence of Resilience. 2nd Symposium on Resilience Engineering, Nov 2006, Juan-les-Pins, France, 9, p. hal-00637892.

Sutcliffe, K. M., \& Vogus, T. J. (2003). Organizing for resilience. In K. Cameron, J. E. Dutton, \& R. E. Quinn (Eds.), Positive Organizational Scholarship (pp. 94110). Berrett-Koehler, San Francisco, CA, Chapter 7.

Sznajder M. (2003). Korzyści z wdrożenia koncepcji społecznej odpowiedzialności biznesu ( $\mathrm{z}$ uwzględnieniem koncepcji interesariuszy) [Benefits from implementing the concept of corporate social responsibility (taking into account the concept of stakeholders)]. Economics and Management, 5(2), 194211. doi: 10.12846/j.em.2013.02.12

Šntaitè-Petkevičienè, M. (2019). Dimensions and attributes building corporate reputation of rural businesses. Research for Rural Development, 2, 175-182.

Szwajca, D. (2016). Corporate reputation and customer loyalty as the measures of competitive enterprise position - empirical analyses on the example of Polish banking sector. Oeconomia Copernicana, 7(1), 91106. doi: 10.12775/OeC.2016.007

Szydło, J., \& Grześ-Bukłaho, J. (2020). Relations between National and Organisational Culture-Case Study. Sustainability, 12, 1522. doi: 10.3390/su12041522

Tengblad, S., \& Oudhuis, M. (2018). The Resilience Framework. Organizing for Sustained Viability. Singapore: Springer Nature.

Tracey N., \& French E. (2017). Influence your firm's resilience through its reputation: Results won't happen overnight but they will happen!. Corporate Reputation Review, 20(1), 57-75. doi: 10.1057/s41299-0170014-7

Ulmer, R. R. (2001). Effective Crisis Management Through Established Stakeholder Relationships. Malden Mills as a Case Study. Management Communication Quarterly, 14(4), 590-615. doi: 10.1177/0893318901144003

Vargo, J., \& Seville, E. (2010). Resilient organizations: Trying to thrive when you are struggling to survive. 4th Annual Business Continuity Summit 2010. Resilience over Uncertainty, University of Canterbury, Christchurch, NZ. 
Vogus, T. J., \& Sutcliffe, K. M. (2007). Organizational resilience: Towards a theory and research agenda, (pp. 3418-3422). IEEE International Conference on Systems, Man and Cybernetics, Montreal, Quebec. doi: 10.1109/ICSMC.2007.4414160.

Walsh, G., Mitchell, V-W., Jackson, P. R., \& Beatty, S. E. (2009). Examining the Antecedents and Consequences of Corporate Reputation: A Customer Perspective. British Journal of Management, 20(2), 187203. doi: 10.1111/j.1467-8551.2007.00557.x

Warren, L., \& Hutchinson W. (2000). Success Factors for High-technology SMEs: A Case Study from Australia. Journal of Small Business Management, 38(3), 8691.

Weigelt, K., \& Camerer, C. (1988). Reputation and corporate strategy: A review of recent theory and applications. Strategic Management Journal, 9, 443-454.

Wicker, P., Filo, K., \& Cuskelly, G. (2013). Organizational Resilience of Community Sport Clubs Impacted by Natural Disasters. Journal of Sport Management, 27, 510-525. doi: 10.1123/jsm.27.6.510 